\title{
Book Review 'Pemeliharaan Dan Pemuliharaan Alam Sekitar Di Malaysia' (Malay Version)
}

\author{
Uqbah iqbal* \\ Faculty of Social Sciences and Humanities, UKM, Bangi Selangor, Malaysia
}

Submission: August 23, 2017; Published: September 21, 2017

*Corresponding author: Uqbah iqbal, Faculty of Social Sciences and Humanities, UKM, Bangi Selangor, Malaysia, Email: uqbah@siswa.ukm.edu.my

\section{Introduction}

Edited by Haliza Abdul Rahman and Rohasliney Hashim, this book is highly relevant published by academics at Universiti Sains Malaysia which scientifically examines environmental issues from the perspective of aquatic environment, land, air and environmental relations with its conservation and conservation management. Environmental and environmental issues are closely linked to today's human life and, more importantly, for future generations. Natural resources need to be preserved due to issues of extinction and resource reductions. If natural resources are renewable, it will take a long time. This process requires a unique conservation management system and strong integrated management. Although this may be possible but the consequence is the increased cost of environmental management in the future and thus we must make a choice between conserving and allowing the extinction of this resource to occur with a constant increase in environmental problems.

Aquatic environments such as rivers, oceans and wetlands are the heart of environmental conservation and the problem of conservation of river ecosystems and the maintenance of macro invertebrates and algae are also very important to be highlighted. Similarly, wetlands or marshes, which are widely seen as noneconomic assets from the perspective of physical development for industrial progress and human settlements in the era of globalization. The degradation of wetlands and marshes in many countries including Malaysia as the physical and infrastructure development pressure is unlikely to be recoverable.

The excess of the swampy soil should be preserved so that it does not continue to be destroyed due to development. Sea pollution due to economic activity and modern lifestyle also results in the loss of a terrible ocean ecosystem. Countries that depend on their economic activities, including Malaysia, are already affected. Similarly, terrestrial environments are indicative of a major problem especially in developed countries with low ecological foot-print values that show a devastating impact on the destruction of natural resources that can no longer be renewed. All of these require a systematic and integrated management efficiency and agreement through a variety of approaches and approaches.

These issues are discussed in depth in this book, which collects writers from various academic backgrounds. Universiti Sains Malaysia encourages the writing of various fields for the inculcation of trans-disciplinary approaches in research, writing and publication and subsequently focusing on real-lifeoriented teaching and learning. Learning or educational needs for sustainable development are essential for future generations. Education for sustainable development is a comprehensive effort across life that challenges individuals, institutions and communities to explore tomorrow's life is all well owned, or tomorrow's life is not the property of anybody because of the destruction pioneered by the present generation.

The Decade of Education on Sustainable Development requires the synergies of all parties including educators, academics, researchers, politicians, educational institutions, societies, businesses, communities and governments to define interpret and transform formal and informal education as the basis of future life sustainability for future generations. This book will also become a part of the academic channel of Universiti Sains Malaysia towards environmental education as a key component of sustainable development-based education for future generations. This book further reinforces the commitment of Universiti Sains Malaysia as the leading institution to explore this challenging field towards the preservation of future life. 
Your next submission with Juniper Publishers will reach you the below assets

- Quality Editorial service

- Swift Peer Review

- Reprints availability

- E-prints Service

- Manuscript Podcast for convenient understanding

- Global attainment for your research

- Manuscript accessibility in different formats ( Pdf, E-pub, Full Text, Audio)

- Unceasing customer service

Track the below URL for one-step submission https://juniperpublishers.com/online-submission.php 